AL-MASHRAFIYAH: Jurnal Ekonomi, Keuangan, dan Perbankan Syariah

ISSN (p): 2597-4904 ISSN (e) : 2620-5661

Volume 3, Nomor 1, April (2019), h. 43-55

https://doi.org/10.24252/al-mashrafiyah.v3i1.7739

\title{
WAKAF TUNAI DAN PEMBERDAYAAN EKONOMI MASYARAKAT
}

\author{
Salmah Said \\ Jurusan Manajemen, Fak. Ekonomi dan Bisnis Islam, UIN Alauddin Makassar \\ salmahsaid@uin-alauddin.ac.id
}

Andi Muhammad Ali Amiruddin

Jurusan Ilmu Hadis, Fak. Ushuluddin dan Filsafat, UIN Alauddin Makassar andiamiruddin@uin-alauddin.ac.id

\section{Keywords: \\ Cash Waqf, \\ Muamalah \\ Activities, Society \\ Economic Welfare.}

Kata Kunci:

Wakaf Tunai,

Kegiatan

Muamalah,

Kesejahteraan

Ekonomi Umat

ABSTRACT

Waqf is one of muamalah activities that has spiritual, social and economic dimensions. Traditionally, waqf has only been interpreted as giving in the form of immovable property such as land and buildings whose designation is limited to the construction of houses of worship and education (schools). However, in fact movable endowments such as cash waqf (money) bas long been practiced by Muslims such as in the Umayyad and Abbasid dynasties, only not as popular as land or building endowments. At present, along with the development of public understanding of the practice of Islamic philanthropy, endowments, especially cash waqf, are directed towards the development and empowerment of the economy, for the sake of fulfilling society economic welfare.

\begin{tabular}{l} 
ABSTRAK \\
\hline Wakaf merupakan salah satu kegiatan muamalah yang memiliki \\
dimensi spiritual, sosial, dan ekonomi. Secara tradisional, selama ini \\
wakaf hanya dimaknai sebagai pemberian dalam bentuk barang tidak \\
bergerak seperti tanah dan bangunan yang peruntukannya terbatas \\
pada pembangunan rumah ibadah dan pendidikan. Namun, sebenarnya \\
wakaf barang bergerak seperti wakaf tunai (uang) telah lama \\
dipraktikkan oleh umat Islam seperti di masa dinasti Umayah dan \\
Abbasiyah, hanya tidak sepopuler wakaf tanah ataupun bangunan. Saat \\
ini, seiring perkembangan pemahaman masyarakat tentang praktik \\
filantropi Islam, wakaf terutama wakaf tunai diarahkan bagi \\
pengembangan dan pemberdayaan ekonomi, untuk sebesar-besarnya \\
peningkatan kesejahteraan ekonomi umat.
\end{tabular}

\section{PENDAHULUAN}

Kemiskinan merupakan masalah bagi semua negara, tidak terkecuali Indonesia. Masalah kemiskinan perlu mendapat perhatian serius dalam penyelesaiannya, karena dapat menimbulkan efek domino pada tatanan sosial masyarakat. Kemiskinan dianggap sebagai salah satu penyebab terjadinya tindak kriminalitas yang tinggi dengan alasan ekonomi. Hal ini sebenarnya dapat diatasi dengan pemberdayaan wakaf sebagai salah satu sumber pendanaan dalam pemberdayaan ekonomi masyarakat (Lestari dan Thantawi, 2016; Saadati, 2016).

Wakaf sebagai salah satu bentuk filantropi (kedermawanan) Islam memiliki potensi cukup besar untuk dikembangkan dan dikelola dalam menciptakan masyarakat lebih produktif. Di Indonesia, lembaga filantropi Islam banyak didirikan dengan salah satu tujuannya adalah 
menyalurkan sumbangan dana masyarakat ekonomi kelas menengah dalam bentuk zakat, infak, sedekah, dan wakaf kepada masyarakat yang dikategorikan sebagai salah satu dari 8 kelompok atau asnaf. Lembaga-lembaga tersebut antara lain BWI (Badan Wakaf Indonesia), RZI (Rumah Zakat Indonesia), DD (Dompet Dhuafa), Baznas, Laznas, PKPU (Pos Keadilan Peduli Umat), dan lembaga-lembaga sosial kemasyarakatan lainnya yang memiliki divisi pemberdayaan zakat, sedekah, infak, dan wakaf. Lembaga-lembaga ini menawarkan diri sebagai lembaga yang menerima dana amaliah ini baik secara individu maupun kolektif (Latif et al, 2015). Dana ini kemudian disalurkan dalam berbagai jenis program kegiatan bagi masyarakat yang membutuhkan.

Selama ini, umumnya umat Islam lebih terfokus pada wakaf yang bersifat benda yang memiliki nilai tinggi, seperti tanah, bangunan, sumur untuk diambil airnya, ataupun pohon yang dapat diambil buahnya (Suganda, 2014). Sedangkan pengelolaan wakaf tunai masih tergolong baru berkembang beberapa tahun terakhir. Terkait dengan wakaf tunai, Fanani (2012) dan Maksum (2010) mengemukakan bahwa persoalan utama pengelolaan wakaf, terutama wakaf uang (tunai) adalah rendahnya kompetensi manajemen pengelolaan wakaf tunai yang diarahkan untuk menyejahterakan masyarakat. Dengan kata lain, wakaf tunai belum diberdayakan sebagai wakaf yang produktif (Rozalinda, 2011; Khairani, 2012; Atabik, 2014; Latif et al, 2915). Sejalan dengan hal ini, Khairani (2012) dan Maksum (2010) menggarisbawahi beberapa permasalahan wakaf di Indonesia antara lain: a). pemahaman bahwa wakaf milik Allah SWT yang tidak boleh diganggu gugat, sehingga wakaf hanya difungsikan sebagai pemenuhan ibadah mabdhah, belum pada tataran wakaf yang berfungsi sosial ekonomi.; b). masih rendahnya pemahaman masyarakat mengenai pemanfaatan wakaf secara produktif; c). kurangnya sinergitas antara pemerintah dan pelaksana teknis wakaf; d). pengelolaan wakaf yang belum optimal karena kurang profesionalnya nazhir (pengelola); e). kerjasama antar lembaga filantropi Islam belum terjalin secara efektif; f). dampak langsung dan tidak langsung dari fluktuasi ekonomi global; dan g). rendahnya inisiasi untuk membuka peluang investor luar (Timur Tengah) untuk mengelola wakaf secara produktif.

Sejalan dengan Khairani, Latif et al (2015) mengemukakan bahwa praktik pemberian wakaf dengan benda tidak bergerak (lahan/tanah/bangunan) merupakan praktik masyarakat pedesaan, dimana masyarakat masih memiliki lahan yang cukup luas untuk disumbangkan untuk pembangunan rumah-rumah ibadah (masjid dan langgar) dan pendidikan (pesantren dan madrasah). Selain itu, pemahaman masyarakat yang menganggap bahwa wakaf hanya merupakan ibadah mahdhah. Sedaangkan, wakaf tunai yang beberapa tahun terakhir ini mulai berkembang, merupakan praktik masyarakat perkotaan dengan alasan lahan yang semakin sempit meningkatkan nilainya, pertumbuhan kelas menengah masyarakat muslim di perkotaan meningkat, kesejahteraannya meningkat, serta ghirah praktik keislaman yang meningkat.

Secara umum, Atabik (2014) membagi periodesasi pengelolaan wakaf dalam tiga periode, yaitu: 1). Periode tradisional, dimana wakaf masih dikategorikan hanya sebagai bagian dari ibadah mahdhah, berupa benda-benda fisik yang tidak bergerak (tanah untuk dibangun masjid, mushalla dan sarana pendidikan (Nadwi dan Kroessin, 2013; Muhammad dan Mubarak, 2018); 2). Periode semi professional: pengelolaan wakaf masih seperti periode tradisional, tetapi juga sudah mulai dikembangkan pemberdayaan wakaf produktif secara sederhana; dan 3). Periode professional: pemberdayaan wakaf secara produktif dan professional sudah marak.

Berkaitan dengan wakaf produktif, Junaidi (2005) menawarkan dua hal penting dalam paradigma baru wakaf (dalam Suganda, 2014) yaitu: 1). Asas Paradigma, yang meliputi; asas keabadian manfaat, asas pertanggungjawaban, asas profesionalistas manajemen, serta asas keadilan; dan 2). Aspek Paradigma, meliputi; reformasi pemahaman mengenai wakaf, sistem manajemen kepengelolaan atau manajemen sumber daya insani dan sistem rekrutmen wakif.

Artikel membahas tentang landasan hukum, baik secara syar'I maupun hukum positif mengenai wakaf secara umum dan wakaf tunai secara khusus. Selain itu, artikel ini juga 
menguraikan perbedaan pendapat ulama erkait dengan wakaf tunai, terdapat beberapa ulama yang membolehkan wakaf tunai, namun beberapa pula yang tidak mengakomodasi adanya wakaf tunai tersebut. Terakhir, artikel ini menganalisis potensi pemanfaatan wakaf tunai dan kendalanya dalam upaya pemberdayaan ekonomi untuk mengentaskan kemiskinan masyarakat.

\section{LANDASAN TEORI}

Sumber hukum dalam Islam adalah al-Qur'an dan hadis, baik yang sifatnya ibadah maupun yang sifatnya muamalah (sosial kemasyarakatan). Wakaf termasuk dalam perkara muamalah. Berbeda dengan kegiatan yang bersifat ibadah yang hukumnya 'segala hal diharamkan kecuali ada dalil yang membolehkannya, kegiatan yang bersifat muamalah hukumnya adalah segala hal dibolehkan kecuali ada dalil yang mengharamkannya (ash Shiddieqy, 1998). Hal ini dikarenakan kegiatan yang dikategorikan muamalah bersifat dinamis dan mengalami perkembangan seiring dengan kemajuan peradaban manusia yang semakin berkembang.

Menurut Muhammad Al-Khatib (dalam Wajdiy dan Mursyid, 2007; Nurfaidah, 2016; Istiqomah, 2016; Nadwi dan Kroessin, 2013; Gustiani dan Ernawan, 2016), wakaf berasal dari bahasa Arab, waqafa berarti menahan atau berhenti, di tempat (plural: awqaf). Secara harfiyah waqf berarti bermakna "pembatasan" atau "larangan", sehingga dapat diartikan sebagai pemilikan dan pemeliharaan harta benda tertentu untuk kemanfaatan sosial dan mencegah penggunaannya di luar tujuan khusus yang telah ditetapkan (Wajdiy dan Mursyid dalam Saadati, 2016). Hal yang paling penting untuk dipahami adalah bahwa wakaf berbeda dari kegiatan zakat, sedekah, berdasarkan keunikan, prinsip, tujuan, metode penerapannya. Pertama, berbeda halnya dengan zakat, infak, dan sedekah, kepemilikan atas barang yang dizakatkan berpindah ke tangan penerima zakat, sedangkan wakaf hanya berpindah kemanfaatan dari wakaf tersebut, bukan kepemilikannya karena kepemilikannya berada di tangan Allah SWT (Nadwi dan Kroessin, 2013; Khairani, 2012, Maksum, 2010). Kedua, jika zakat, infak, dan sedekah memenuhi kebutuhan segera dari sipenerima, lain halnya dengan wakaf memberi peluang kesinambungan manfaat dan tujuan khusus bagi penerima wakaf (Abu Zuhra dalam Nadwi dan Kroessin, 2013).

Jika ditelusuri ayat demi ayat dalam Al-Qur'an, maka tidak ditemukan secara eksplisit ayat yang menguraikan konsep wakaf. Yang lebih banyak dinyatakan adalah infak di jalan Allah SWT (infaq fi sabilillah), para ulama kemudian menyandarkan dasar konsep wakaf ini pada ayatayat infaq fi sabilillab ini. Hal ini berbeda dengan pembahasan zakat dimana diuraikan dengan jelas dalam al-Qur'an.

Dalam QS. Al-Baqarah: 267 dinyatakan bahwa Allah memerintahkan manusia untuk menafkahkan sebagian dari hasil usaha yang telah dilakukan di muka bumi yang baik-baik, tanpa memilah yang buruk saja. Bila dikaitkan dengan tujuan dari pemberian waqaf, ayat ini mengindikasikan pemberian hasil usaha yang memiliki nilai manfaat yang maksimal. Pernyataan al-Qur'an tentang hasil usaha yang baik-baik dan si pemberi nafkah menyukai harta yang diberikannya mengindikasikan bahwa harta tersebut memiliki nilai tambah bagi si penerima pemberian. Nilai tambah tersebut, dapat berjangka pendek, dapat pula berjangka panjang.

Hal senada dapat ditemukan dalam QS. Al-Baqarah: 261 dimana perumpamaan harta yang dikeluarkan yang bernilai fi sabilillah adalah satu menjadi tujuh, dan masing-masing dari tujuh tersebut menghasilkan seratus. Perumpamaan ini menunjukkan bahwa tiadalah pemberian yang dikeluarkan oleh umat manusia kecuali memberikan manfaat yang sangat besar bagi kedua belah pihak, baik yang diberi maupun yang memberi. Kemanfaatan bagi yang diberikan akan bermakna lebih dalam dan lebih luas bila pemberian tersebut dapat dikembangkan dalam bentuk apa pun untuk sebesar-besarnya kebutuhan umat manusia, dan 
Salmah Said, dan Andi Muhammad Ali Amiruddin. Wakaf Tunai dan ...

janji Allah untuk melipatgandakan, tidak saja pemberian tersebut secara materil, tetapi juga non materil berupa ganjaran pahala di sisi-Nya.

Setiap pemberian dari harta atau hasil usaha yang dilakukan umat manusia, akan bernilai pahala yang tinggi di sisi Allah jika pemberian tersebut dikeluarkan sejalan dengan QS. Al-Baqarah: 262, di mana Allah menekankan untuk tidak mengiringi apa yang dinafkahkan itu dengan menyebut-nyebut pemberian tersebut, apatah lagi menyakiti perasaan penerima pemberian. Bila hal tersebut terjadi, tidak saja menimbulkan kekhawatiran dan kegundahan di sisi penerima, tetapi juga tidak akan mendapatkan nilai pahala bagi pihak pemberi. Hal ini berimbas pada pemanfaatan harta yang telah diberikan yang bisa jadi tidak akan mencapai titik maksimal pemanfaatan karena menimbulkan riak yang kurang berkenan di sisi penerima.

Kesempurnaan sebuah pemberian terletak pada seberapa besar nilai tambah dari pemberian tersebut. Jika pemberian tersebut hanyalah berupa barang yang tidak memiliki nilai tambah bagi si penerima, maka sinyal QS. Ali Imran: 92 dengan tegas mengindikasikan bahwa pemberian tersebut tidak akan memiliki nilai kebaikan yang paripurna. Merujuk pada paparan al-Qur'an tentang infak $f i$ sabilillah, dapat dipahami bahwa infak untuk memenuhi kebutuhan yang berjangka panjang, memiliki nilai tambah yang sangat besar dan menunjukkan kesempurnaan dari pemberian itu. Pengejawantahan dalam bentuk wakaf, merupakan salah satu bentuk aplikasi langsung upaya untuk pemenuhan nilai tambah yang berjangka panjang dan berdaya guna, baik secara materil bagi si penerima, maupun secara non materil bagi si pemberi.

Dalam konteks wakaf di Indonesia secara khusus, Fuadi (2018) dan Abulyatama (2017) mengemukakan bahwa Majelis Ulama Indonesia juga telah mengeluarkan fatwa mengenai wakaf tunai (uang), yaitu:

1. Wakaf uang (cash waqf/waqf al-nuqud) adalah wakaf yang dilakukan oleh sekelompok atau seseorang maupun badan hukum yang berbentuk wakaf tunai.

2. Termasuk dalam pengertian uang adalah surat-surat berharga.

3. Wakaf yang hukumnya jawaz (boleh)

4. Wakaf yang hanya boleh disalurkan dan digunakan untuk hal-hal yang dibolehkan secara syari.

5. Nilai pokok wakaf yang harus dijamin kelestariannya, tidak boleh dijual, dihibahkan atau diwariskan.

Lahirnya Undang-Undang Nomor 41 Tahun 2004 adalah bentuk dukungan pemerintah terhadap fatwa MUI ini. Aturan kemudian diperkuat dengan keluarnya Peraturan Pemerintah Nomor 42 Tahun 2006 tentang Pelaksanaan UU No. 41 Tahun 2004 tentang wakaf, Pasal 1 ayat 7 terkait wakaf uang. Dalam hukum positif, wakaf diatur dalam Undangundang Nomor 41 tahun 2004 tentang Wakaf, Pasal 1 dikemukakan bahwa:

"Wakaf adalah perbuatan bukum wakif untuk memisabkan dan/atau menyerabkan sebagian harta benda miliknya untuk dimanfaatkan selamanya atau untuk jangka waktu tertentu sesuai dengan kepentingannya guna keperluan ibadah dan/atau kesejabteraan umum menurut syariab".

Sedangkan pada Pasal 5 diuraikan fungsi wakaf, yaitu sebagai salah satu sarana untuk mewujudkan potensi dan manfaat ekonomis harta benda wakaf untuk kepentingan ibadah dan untuk memajukan kesejahteraan umum. Kesejahteraan umum dapat diartikan dalam bentuk peningkatan penghasilan, mampu menyediakan lapangan pekerjaan tidak saja bagia dirinya secara individu, tetapi juga mampu menciptakan lapangan pekerjaan bagi masyarakat sekitarnya. Dengan demikian, taraf hidup diri dan keluarganya meningkat dan pada saat yang bersamaan juga secara signifikan meningkatlan taraf ekonomi masyarakat secara luas. Selanjutnya, pada Pasal 16 Undang-Undang tersebut diuraikan mengenai jenis-jenis wakaf, termasuk wakaf tunai sebagaimana diuraikan secara detil di bawah ini:

(1) Harta benda wakaf terdiri dari: 
AL-MASHRAFIYAH: Jurnal Ekonomi, Keuangan, dan Perbankan Syariah

Volume 3, Nomor 1, April 2019

a. benda tidak bergerak; dan

b. benda bergerak.

(2) Benda tidak bergerak sebagaimana dimaksud pada ayat (1) huruf a meliputi:

a. hak atas tanah sesuai dengan ketentuan peraturan perundang-undangan yang berlaku baik yang sudah maupun yang belum terdaftar;

b. bangunan atau bagian bangunan yang berdiri di atas tanah sebagaimana dimaksud pada huruf a;

c. tanaman dan benda lain yang berkaitan dengan tanah;

d. hak milik atas satuan rumah susun sesuai dengan ketentuan peraturan perundangundangan

e. yang berlaku;

f. benda tidak bergerak lain sesuai dengan ketentuan syariah dan peraturan perundangundangan yang berlaku.

(3) Benda bergerak sebagaimana dimaksud pada ayat (1) huruf b adalah harta benda yang

tidak bisa habis karena dikonsumsi, meliputi:
a. uang;
b. logam mulia;
c. surat berharga;
d. kendaraan;
e. hak atas kekayaan intelektual;
f. hak sewa; dan
g. benda bergerak lain sesuai dengan ketentuan syariah dan peraturan perundang-undangan yang berlaku.

Dari sisi syariah, beberapa hadis Nabi SAW terkait dengan wakaf antara lain (Abulyatama, 2017; Kementerian Agama, 2013; Fuadi, 2018; Nurfaidah, 2016):

a. Dari Abu Hurairah ra diriwayatkan bahwa Rasulullah SAW bersabda: "Apabila manusia meninggal dunia, terputuslah (pahala) amal perbuatannya kecuali dari tiga hal yaitu kecuali dari sedekah jariyah (wakaf), ilmu yang dimanfaatkan, atau anak shaleh yang mendo'akannya." (H.R. Muslim, al-Tirmidzi, al-Nasa'i, dan Abu Daud).

b. Diriwayatkan dari Ibnu Umar ra bahwa Umar bin al-Khaththab ra memperoleh tanah (kebun) di Khaibar; lalu ia datang kepada Nabi SAW untuk meminta petunjuk mengenai tanah tersebut. Ia berkata: "Wahai Rasulullah, saya memperoleh tanah di Khaibar; yang belum pernah saya peroleh harta yang lebih baik bagiku melebihi tanah tersebut; apa perintah Engkau (kepadaku) mengenainya?" Nabi Saw. menjawab: "Jika mau, kamu tahan pokoknya dan kamu sedekahkan (hasil)nya." Ibnu Umar berkata, "maka, Umar menyedekahkan tanah tersebut, (dengan mensyaratkan) bahwa tanah itu tidak dijual, tidak dihibahkan, dan tidak diwariskan. Ia menyedekahkan (hasil)-nya kepada fuqara, kerabat, riqab (hamba sahaya, orang tertindas), sabilillah, ibnu sabil, dan tamu. Tidak berdosa atas orang yang mengelolanya untuk memakan dari (hasil) tanah itu secara ma'ruf (wajar) dan memberi makan (kepada orang lain) tanpa menjadikannya sebagai harta hak milik." Rawi berkata, "Saya menceritakan hadis tersebut kepada Ibnu Sirin, lalu berkata 'ghaira muta'tsilin makan (tanpa menyimpannya sebagai harta hak milik)." (H.R. alBukhari, Muslim, al-Tirmidzi, dan al-Nasa'i).

c. Diriwayatkan dari Ibnu Umar ra; ia berkata, Umar ra berkata kepada Nabi Saw., "Saya mempunyai seratus saham (tanah, kebun) di Khaibar, belum pernah saya 
Salmah Said, dan Andi Muhammad Ali Amiruddin. Wakaf Tunai dan ...

mendapatkan harta yang lebih saya kagumi melebihi tanah itu; saya bermaksud menyedekahkannya." Nabi SAW berkata, "Tahanlah pokoknya dan sedekahkan buahnya pada sabilillah.” (H.R. al-Nasa'i).

d. Selain itu, Jabir ra berkata: "Tak ada seorang sahabat Rasulpun yang memiliki kemampuan kecuali berwakaf."

Wakaf merupakan amal jariyah yang akan dinikmati kemanfaatannya, selama digunakan. Dengan kata lain, wakaf memiliki dimensi sosial ekonomi selain dimensi spiritual, yaitu ketaatan pada perintah Allah swt. Hal ini menjadi alasan pelarangan harta wakaf untuk dijual. Tuasikal (2016) mengemukakan pelarangan beberapa ulama mendasarkan hal ini, seperti Imam Malik dan Imam Syafi'i. Sedangkan Imam Abu Hanifah menyatakan kebolehan wakaf untuk dijual. Imam Ahmad juga berpendapat bahwa wakaf boleh dijual dan diganti tetapi dengan syarat hanya apabila manfaat harta wakaf tidak ada lagi secara total atau tidak mungkin diperbaiki lagi (Tuasikal, 2016). Ulama yang berpendapat bahwa harta wakaf juga dapat dijual adalah Ibnu Taimiyah, yang berpendapat bahwa jika lebih memberi kemaslahatan, maka harta wakaf boleh dijual (Tuasikal, 2016).

\section{METODE PENELITIAN}

Penelitian ini merupakan penelitian kualitatif yaitu kajian pustaka. Pendekatan yang digunakan adalah deskriptif analitis kritis. Jenis dan sumber data adalah data sekunder yang diperoleh dari hasil penelitian, artikel dan buku-buku referensi yang membahas topik yang sama.

\section{HASIL DAN PEMBAHASAN}

Wakaf telah dipraktikkan sebelum datangnya Islam, namun hanya bertujuan untuk memperoleh kebanggaan (prestise) kalangan kaum bangsawan di mata masyarakatnya. Sedangkan pada masa Islam, praktik wakaf telah disyariatkan pada tahun kedua hijriyah (Nurfaidah, 2016; Tho'in dan Prastiwi, 2015; Huda, et.al, 2016) dan juga telah dilakukan oleh Rasulullah dengan mewakafkan tanahnya untuk dibangun masjid (Tho'in dan Prastiwi, 2015; Nurfaidah, 2016). Namun sebagian ulama menyatakan bahwa praktik wakaf pertama kali dilakukan oleh Umar bin Khattab berdasarkan hadis Ibnu Umar di atas. Pada masa dinasti Umayah, dinasti Abbasiyah dan dinasti setelahnya, perkembangan praktik wakaf juga terjadi, dimana wakaf berfungsi untuk membantu fakir-miskin, menjadi modal untuk membangun lembaga pendidikan serta membayar gaji para guru (Tho'in dan Prastiwi, 2015).

Nadwi dan Kroessin (2013), Junaidi (2017), serta Hamber dan Haneef (2017) mengemukakan bahwa wakaf merupakan praktik sosial yang sangat dianjurkan karena merangkum dimensi spiritual, sosial dan ekomomi. Wakaf memiliki dimensi spiritual karena pelaksanaan wakaf merupakan salah implementasi dari perintah Allah swt dalam Al-Qur'an. Di satu sisi, wakaf juga memiliki dimensi sosial dan ekonomi, karena dengan wakaf (terutama tanah dan bangunan), masyarakat memperoleh manfaat dari dibangunnya tanah wakaf menjadi sarana ibadah (masjid, musholla, dan langgar) dan sarana pendidikan (pesantren dan madrasah). Namun selama ini, secara tradisional, wakaf selalu dikaitkan dengan wakaf barang (tanah, bangunan) yang menghasilkan keuntungan sosial secara langsung seperti rumah sakit, sekolah atau secara tidak langsung keuntungan dari penyewaan barang wakaf tersebut.

Beberapa ulama melarang praktik wakaf uang antara lain seperti Ibnu Qudamah (Qudamah, 1997), al-Syirazi, dan al-Bakri (Athoillah, 2014). Larangan praktik wakaf uang terletak pada aspek kekekalan zat harta wakaf, yang didasarkan pada hadis Rasulullah SAW yang memerintahkan Umar r.a untuk 'menahan pokoknya dan menyedekahkan hasilnya'. Sementara uang jika dimanfaatkan zatnya akan langsung habis, sehingga tidak kekal (Paksi et 
al, 2018; Abulyatama, 2017). Selain itu argumentasi Ibnu Qudamah terkait pelarangannya adalah bahwa dalam konsep ekonomi Islam uang tidak boleh menghasilkan keuntungan kecuali diputar dalam sektor produksi. Ini terjadi apabila uang disewakan untuk memperoleh keuntungan karena ingin tetap mempertahankan kekekalannya, tidak habis sekali pakai (Saadati, 2016).

Menurut Murat Cizakca dalam Arif (2010) (lihat pula Muhammad dan Mubarak, 2018), pertama kali wakaf tunai (cash waqf) digunakan di akhir abad ke-16 (1555-1823 M, yaitu pada masa kekuasaan Turki Utsmani di Mesir. Bahkan seluruh daerah di bawah kekuasaan Turki Utsmani (daerah Antonia, Eropa, Timur Tengah, dan Afrika Utara) menerima penerapan wakaf tunai yang kemudian digunakan untuk membeli/membangun beberapa asset tetap seperti sekolah, rumah sakit, jembatan, bendungan, pelabuhan, dan mercusuar (Pitchay, et.al, 2015).

Imam Muhammad asy-Syaibani menjelaskan bahwa penggunaan harta bergerak sebagai wakaf dibolehkan, jika memang hal itu sudah menjadi kebiasaan umum pada daerah tertentu (Paksi, dkk, 2018; Tho'in dan Prastiwi, 2015). Sejalan dengan asy-Syaibani, Imam Hanafi juga membolehkan wakaf tunai (Zuhaili, 1985), Imam Zuhri (Abulyatama, 2017; Isfandiar dalam Paksi, dkk, 2018); Abu Tsaur (Abulyatama, 2017; al-Mawardi, 1994), serta asy-Syaibani (Sulistiani, 2017). Imam Zuhri berpendapat bahwa pemanfaatan wakaf uang yaitu dengan cara menjadikannya sebagai modal usaha dengan akad bagi hasil, yang kemudian keuntungannya disedekahkan (Paksi, dkk, 2018). Asy-Syaibani juga berpendapat bahwa apabila wakaf uang telah menjadi kebiasaan di suatu daerah maka tidak mengapa untuk dilanjutkan (Sulistiani, 2017). Demikian pula halnya terkait dengan aspek kekekalan harta wakaf, ulama yang membolehkan wakaf tunai berpendapat bahwa wakaf tunai memiliki kekekalan manfaat.

Hal ini dapat dipahami secara logis dengan contoh wakaf tunai yang dimanfaatkan sebagai modal usaha, membayar biaya pelatihan keterampilan kerja, serta digunakan untuk membangun sarana perdagangan yang biaya sewanya terjangkau bagi masyarakat berpenghasilan rendah, dan program pemberdayaan ekonomi lainnya. Kekekalan manfaatnya dapat diukur pada kontinuitas usaha yang akhirnya dapat meningkatkan taraf kesejahteraan masyarakat, bahkan dapat membuka lapangan kerja bagi masyarakat lainnya. Selain itu, wakaf tunai untuk membiayai pelatihan keterampilan kerja juga memberi peluang bagi masyarakat untuk memperoleh pekerjaan yang lebih baik. Selanjutnya, pembangunan sarana perdagangan dengan biaya sewa yang rendah bagi masyarakat turut mendukung pemberdayaan sosial ekonomi masyarakat. Dengan demikian, unsur kekekalan manfaat dari wakaf tunai juga terpenuhi, sama halnya dengan kekekalan manfaat dari wakaf asset atau barang tidak bergerak (tanah dan bangunan).

Wakaf tunai dianggap lebih fleksibel dalam penggunaannya daripada jenis wakaf barang tidak bergerak (tanah dan bangunan) terutama dalam hal pemberdayaan ekonomi masyarakat. Wakaf tunai dapat digunakan untuk membeli asset atau diinvestasikan pada instrumen pasar modal seperti sukuk atau saham (Nadwi dan Kroessin, 2013; Junaidi, 2017; Muhammad dan Mubarak, 2018), juga dapat langsung digunakan sebagai tambahan modal usaha-usaha produktif. Muhammad dan Mubarak (2018) dan Pitchay et al, (2015) dalam penelitiannya mengemukakan bahwa meskipun wakaf barang tidak bergerak ini dirasakan manfaatnya untuk kepentingan publik (sebagai tempat ibadah, tanah pemakaman, saluran air/bendungan, serta madrasah dan pesantren), namun jenis wakaf ini memiliki keterbatasan manfaat dari sudut pandang ekonomi. Jenis wakaf ini tidak membantu masyarakat mengatasi masalah sosial ekonomi mereka, yaitu tidak meningkatkan kesejahteraan mereka melalui pemberdayaan usaha-usaha ekonomi yang produktif. Wakaf barang tidak bergerak tidak mampu mengatasi keterbatasan atau ketiadaan modal bagi usaha baik bagi usaha baru (start-up) maupun usaha yang sudah ada (existing business). Wakaf tanah dan bangunan juga tidak mengakomodasi kebutuhan modal besar untuk ekspansi usaha. Terlebih lagi wakaf tanah mengalami periode 
Salmah Said, dan Andi Muhammad Ali Amiruddin. Wakaf Tunai dan ...

stagnan, bahkan mengalami trend penurunan karena adanya penjajahan negara-negara muslim (Aun, 1975 dalam Pitchay et al., 2015; Huda et al, 2014).

Selain itu, adanya kecenderungan migrasi masyarakat pedesaan ke daerah perkotaan (urban), yang akhirnya turut memengaruhi semakin sempitnya lahan-lahan di daerah perkotaan sehingga berkonribusi signifikan pada penurunan minat dan jumlah lahan yang diwakafkan (Fanani, 2011). Sempitnya lahan di daerah perkotaan mendorong harga tanah menjadi mahal, sehingga kepemilikan lahan secara pribadi umumnya diperuntukkan untuk pemenuhan kebutuhan dasar (basic needs), yaitu untuk rumah. Hal ini menjadi fenomena umum, terutama pada golongan masyarakat ekonomi menengah. Sementara, di satu sisi, masyarakat juga ingin mengimplementasikan perintah Allah swt sebagai bentuk ketundukan abd' (hamba) terhadap Rabb-nya. Di sinilah peluang wakaf tunai untuk berkembang dan menjadi alternatif terpenuhinya dimensi spiritual wakaf tersebut.

Saat ini, wakaf tunai banyak dipraktikkan di negara muslim, seperti di Kuwait terdapat Kuwait Awqaf Publik Foundation (KAPF) yang menciptakan beberapa wakaf tunai untuk berbagai tujuan. Ada dana wakaf untuk masjid, cacat dan cacat, pelestarian al-Qur'an serta pendidikan dalam bentuk penelitian ilmiah dan inovasi (Abdel Mohsin, 2009; dan Cizakca, 1998 dalam Hamber dan Haneef, 2017). Wakaf tunai juga semakin popular di kalangan muslim di Malaysia, karena lembaga-lembaga wakaf juga mendorong peningkatan kontribusi wakaf tunai untuk mengembangkan wakaf lahan yang belum digarap (Pitchay, et al., 2015). Perkembangan ini juga didukung oleh pemerintah Malaysia yang memberikan insentif pengecualian pajak bagi pendonor wakaf tunai, meskipun hal ini tidak signifikan meningkatkan wakaf tunai secara total (Pitchay, et al., 2015).

Di Indonesia, praktik wakaf tunai juga berkembang dengan keluarnya fatwa MUI yang didukung oleh terbitnya Undang-Undang Nomor 41 tahun 2004 dan Peraturan Pemerintah Nomor 42 Tahun 2006 sebagai petunjuk teknis pelaksanaannya. Hadirnya peraturan ini memberi peluang pemanfaatan wakaf ke arah yang lebih luas, yaitu pemberdayaan dan peningkatan sosial ekonomi umat. Wakaf tunai kemudian mulai dipraktikkan dengan dipelopori oleh beberapa lembaga keuangan syariah seperti Badan Wakaf Indonesia, Tabungan Wakaf Indonesia (TWI), PKPU, dan BMM (Fanani, 2011; Nafis, 2012; Tho'in dan Prastiwi, 2015). Pemerintah melalui BWI terus menggalakkan dan mengkampanyekan penggalangan wakaf tunai baik secara nasional maupun internasional, sedangkan pengelolaan tingkat nasional dan lokal pemerintah mendorong lembaga-lembaga wakaf yang telah lama dikelola oleh masyarakat (Nafis, 2012). Bahkan, Sadeq (2002) menawarkan penerbitan sertifikat wakaf oleh institusi wakaf yang dapat digunakan untuk membangun proyek dalam rangka mengentaskan kemiskinan dan pemberdayaan sosial ekonomi masyarakat.

Selanjutnya wakaf tunai yang terkumpul ini disalurkan atau diinvestasikan oleh nąhir ke dalam berbagai sektor usaha yang halal dan produktif, seperti pembangunan kawasan perdagangan yang ditujukan bagi masyarakat miskin dengan biaya sewa yang rendah. Hal ini dapat mendorong pemberdayaan ekonomi di sektor riil. Wakaf tunai sebagai modal menjadi solusi alternatif karena usaha-usaha produktif masyarakat yang dikategorikan usaha ekonomi mikro dapat ditopang dengan pemberian modal. Usaha kecil mikro ini umumnya merupakan non-bankable institution, tidak terjangkau oleh layanan perbankan, karena terkendala pemenuhan kriteria pemberian kredit yang dipersyaratkan oleh bank (Character, Capacity, Capital, Collateral, Condition). Wakaf tunai dapat pula difasilitasi penyalurannya oleh lembaga keuangan mikro (Muhammad dan Mubarak, 2018) seperti Baitul Maal wat Tamwil atau BMT (Said, 2012; Gustiani dan Ernawan, 2016; Novitasari, 2018).

Sama seperti wakaf barang, pengelolaan wakaf tunai juga membutuhkan kemampuan manajemen dan akuntabilitas (transparansi, responsibilitas, dan independensi) dari pengelolanya (Huda, 2014; Baharuddin dan Iman, 2018). Menurut Huda, et.al (2016) terdapat tiga factor berkontribusi signifikan pada pengelolaan wakaf, yaitu regulator, ną̧ hir (pengelola wakaf), dan wakif (pemberi wakaf). Huda, et.al (2016) menyimpulkan bahwa dari sisi regulator, 
perlu tambahan alokasi dana APBN untuk melakukan sertifikasi wakaf (tanah/lahan). Dari sisi rendahnya pemahaman wakif, diperlukan sosialisasi untuk meningkatkan pemahaman wakaf terutama wakaf tunai melalui media cetak dan elektronik. Terakhir, terkait kompetensi naz̧hir yang masih rendah menjadi salah satu kendala manajemen dalam pengelolaan wakaf. Untuk itu, diperlukan pelatihan intensif tentang pengelolaan wakaf.

Kendala yang dihadapi dalam pengelolaan wakaf tanah/lahan juga secara umum menjadi kendala bagi pengelolaan wakaf tunai, terutama dua faktor terakhir yaitu terkait pemahaman dan kompetensi naz̧bir serta pemahaman wakif tentang wakaf tunai. Pemahaman nazhir tentang kebolehan wakaf tunai berdasarkan pendapat beberapa ulama perlu ditingkatkan dengan memberi pelatihan pendalaman mengenai fikih muamalah.

Huda, et. al (2014) mengemukakan bahwa pelatihan intensif bagi nazhir penting dilakukan untuk meningkatkan akuntabilitas pengelolaan lwakaf, sehingga profesionalitas pengelolaan wakaf ini dapat terwujud agar kepercayaan masyarakat semakin meningkat. Hal ini juga didukung oleh riset yang dilakukan oleh Tumirin et al, (2017) menunjukkan bahwa akuntabilitas transendental dan sosial dalam pengelolaan aset wakaf sebagai kepercayaan dari Tuhan. Selain itu, pelatihan manajemen pengelolaan wakaf tunai akan meningkatkan dan mengembangkan kompetensi naz̧hir, sehingga wakaf tunai ini dapat memberi kemanfaatan yang lebih luas dalam meningkatkan ekonomi dan kesejahteraan masyarakat.

Pemahaman yang komprehensif tentang wakaf tunai tidak saja dibutuhkan oleh para wakif tetapi juga masyarakat secara umum. Solusi untuk hal ini adalah dengan sosialisasi secara sistematis dan kontinu serta komprehensif kepada semua lapisan masyarakat. Sosialisasi ini terutama dibutuhkan sebagai bentuk pencerahan tentang kebolehan wakaf tunai, fleksibilitas penggunaannya, serta kontinuitas manfaat yang diperoleh dari wakaf tunai terutama dalam hal membangun usaha-usaha produktif yang meningkatkan kesejahteraan serta ekonomi masayrakat secara lebih luas. Pada ranah inilah pemerintah diharapkan dapat berperan aktif dalam membantu masyarakat mewujudkan dimensi spiritual dan sosial ekonomi dari wakaf tunai tersebut.

\section{PENUTUP}

Berbeda halnya dengan zakat, infak, dan sekdekah, wakaf memiliki keunikan tersendiri dalam hal prinsip, tujuan, dan metode penerapannya. Wakaf, terutama wakaf tunai, dapat memberi kontribusi signifikan pada pengentasan kemiskinan dengan berbgai program dan kegiatan pengembangan dan pemberdayaan ekonomi umat. Meskipun para ulama berbeda pendapat tentang kebolehan jenis wakaf tunai ini, tidak dapat dipungkiri bahwa wakaf tunai memiliki fleksibilitas dalam hal penggunaannya terutama dalam pemberdayaan sosial ekonomi masyarakat. Wakaf tunai ini dapat menjadi salah satu sumber pemodalan bagi usaha-usaha produktif masyarakat yang kadangkala belum terjangkau layanan perbankan karena persyaratan agunan (collateral). Namun, pengelolaan wakaf tunai bukan pula suatu pekerjaan mudah. Kompetensi manajerial dan akuntabilitas (transparansi, responsibilitas, serta independensi) nazhir menjadi tantangan yang perlu dipenuhi dalam pengelolaan dan pemanfaatan wakaf tunai yang lebih produktif dalam pemberdayaan ekonomi umat. Selain itu, perlunya dilakukan sosialisasi yang sistematis, kontinu, dan komprehensif tentang wakaf tunai sehingga dimensi spiritual dan sosial ekonomi wakaf tunai ini dapat dirasakan secara luas oleh masyarakat. 
Salmah Said, dan Andi Muhammad Ali Amiruddin. Wakaf Tunai dan ...

\section{DAFTAR PUSTAKA}

Al-Qur'an dan Terjemahnya.

Abulyatama. 2017. Keputusan Fatwa Komisi Fatwa Majelis Ulama Indonesia tentang Wakaf Uang, diakses dari http://www.abulyatama.or.id/artikel/read/khazanah-islam/17/keputusanfatwa-komisi-fatwa-majelis-ulama-indonesia-tentang-wakaf-uang tanggal 26 Februari 2019.

Alani, Usama Abdulmajed; Algodah, Mohamad T.S; Alshwaiyat Mahmoud Saleem. 2016. Role of Waqf (Endowment) Funds in Financing Small Projects, Global Business and Management Research: An International Journal, Vol. 8, No. 2.

Al Arif, M Nur Rianto. 2012. The Cash Waqf Multiplier Effect And The Influence To Poverty Alleviation Program, Jurnal Asy-Syir'ah, Vol. 46, No. I, Januari - Juni, blm 297 - 314.

Al Arif, M. Nur Rianto. 2012. Wakaf Uang dan Pengaruhnya terhadap Program Pengentasan Kemiskinan di Indonesia, Jurnal Indo-Islamika, Volume 2, Nomor 1,

Al Arif, M. Nur Rianto. 2010. Pemberdayaan Masyarakat Berbasis Wakaf Uang. Jurnal AsySyir'ah, Vol. 44, No. II tabun 2010, blm. $813-828$.

Arif, Syafrudin. 2010. Wakaf Tunai sebagai Alternatif Mekanisme Redistribusi Keuangan Islam, Jurnal La Riba, Vol. IV No. 1, Juli.

Atabik, Ahmad. 2014. Manajemen Pengelolaan Wakaf Tunai di Indonesia, Jurnal ZISWAF, Vol. 1, No. 1, Juni.

Athoillah, H.M. 2014. Hukum Wakaf. Bandung: Penerbit Yrama Widya.

Aziz, M. Wahib. 2017. Wakaf Tunai dalam Perspektif Hukum Islam. International Journal Ibya' Ulum Al-Din Vol 19 No 1. DOI: 10.21580/ihya.18.1.1740

Baharuddin, A. Zamakhsyari dan Rifqi Qowiyul Iman. 2018. Nazir Wakaf Profesional, Standarisasi dan Problematikanya, Li Falah, Jurnal Studi Ekonomi dan Bisnis Islam Volume 3, Nomor 2, Desember.

Fadhilah, Nur. Wakaf Tunai: Potensi dan Alternatif Pengelolaan, diakses dari https://www.academia.edu/36087118/Wakaf Tunai Potensi dan Alternatif Pengelol $\underline{\text { aan }}$

Fanani, Muhyar. 2011. Pengelolaan Wakaf Tunai, WALISONGO: Jurnal Penelitian Sosial Keagamaan, Volume 19, Nomor 1, Mei.

Fuadi, Nasrul Fahmi Zaki. 2018. Wakaf sebagai Instrumen Ekonomi Pembangunan Islam, Economica: Jumal Ekonomi Islam, Volume 9, Nomor 1

Ghofur, Ruslan Abdul; Isnayati Nur. 2013. Pemberdayaan Masyarakat Melalui Optimalisasi Pengelolaan Wakaf Tunai (Studi Kasus pada LAZ Baitul Maal Hidayatullah dan Yatim Mandiri Cabang Lampung), INFERENSI: Jurnal Penelitian Sosial Keagamaan, Vol. 7, No. 2, Desember. 
AL-MASHRAFIYAH: Jurnal Ekonomi, Keuangan, dan Perbankan Syariah

Volume 3, Nomor 1, April 2019

Gustani dan Dwi Aditya Ernawan. 2016. Wakaf Tunai sebagai Sumber Alternatif Permodalan Lembaga Keuangan Mikro Syariah di Indonesia. Journal of Islamic Economics Lariba Vol. 2, Issue 2: 39-48, DOI : 10.20885/jielariba.vol2.iss2.art2

Hamber, Norliana Mohammad. 2017. Waqf-Based Social Micro Venture Fund: A Proposal for the Malay-Muslim Community in Singapore, JKAU: Islamic Econ., Vol. 30 No. 1, pp: 3760 January, DOI: 10.4197 / Islec. 30-1.3

Hasan, Sudirman. Wakaf Uang dan Implementasinya di Indonesia, diakses dari https://media.neliti.com/.../23638-ID-wakaf-uang-dan-implementasi..., tanggal 5 Maret 2019.

Huda, Nurul; Nova Rini, Yosi Mardoni, Desti Anggraini, Khamim Hudori. 2016. Manajemen Pengelolaan Wakaf di Indonesia Timur. EKUITAS: Jurnal Ekonomi dan Kenangan ISSN 1411 - 0393 Akreditasi No. 80/DIKTI/Kep/2012.

Huda, Nurul; Desti Anggraini; Nova Rini; Hudori; Yosi Mardoni. 2014. Akuntabilitas Sebagai Sebuah Solusi Pengelolaan Wakaf. Jurnal Akuntansi Multiparadigma, JAMAL, Volume 5, Nomor 3, H. 345-510, Malang, Desember, PISSN 2086-7603, EISSN 2089-5879.

Istiqomah, Abdullah. 2016. Hadits-hadits tentang Wakaf beserta Arti dan Penjelasannya, diakses dari http://fimadani.com/hadits-tentang-wakaf/, tanggal 15 Februari 2019.

Junaidi, Ebi. 2017. "When Waqf Meets Banks". The World Financial Review, May 30, 2017, diakses dari http://www.worldfinancialreview.com/?p=17886, tanggal 26 Maret 2019.

Kementerian Agama Republik Indonesia. 2013. Panduan Pengelolaan W akaf Tunai. .

Khairani, Eddy. 2012. Strategi Pengembangan Wakaf Produktif, makalah disampaikan pada Oreintasi Nazhir dan Pengembangan Wakaf Produktif Se-Kabupaten Tapin, wnw.academia.edu/.../STRATEGI PENGEMBANGAN WAKAF ..., diakses tanggal 26 Februari 2019.

Latief, Hilman; Syarif As'ad; Miftakhul Khasanah. 2015. Fleksibilitas Pemaknaan Wakaf Tunai di Indonesia: Studi terhadap Lembaga Filantropi dan Lembaga Keuangan, AFKARUNA: Jurnal Imu-Ilmu Keislaman Vol. 11 No. 1 Juni.

Lestari, W. dan R.Thantawi, 2016. Efektivitas Pengelolaan Wakaf Tunai di Badan Wakaf Indonesia, Jurnal Syarikab ISSN 2442-4420 Volume 2 Nomor 1, Juni,

Maksum, Muhammad. 2010. Manajemen Investasi Wakaf Uang. MUQTASID: Jurnal Ekonomi dan Perbankan Syariah, Vol. 1 No. 1.

al-Mawardi, Mahmud Mathraji. 1994. Al-Hawi al-Kabir. Beirut: Darul Fikr.

Muhammad, Abu Su'ud. 1997. Risalah fi Jawari Waqf al-Nuqud. Beirut: Dar Ibn Hazm, h.20-21.

M, Nurfaidah. 2016. Wakaf dan Pemberdayaan Ekonomi Syariah, Jurnal Al-'Adl, Vol. 9 No. 1 , Januari.

Muhammad, Ibrahim Nuruddeen and Abba Mubarak. 2018. Islamic Financial Inclusion for Women Empowerment: Imperative for Establishing Cash Waqf for Preventing Rural-Urban Girl- 
Salmah Said, dan Andi Muhammad Ali Amiruddin. Wakaf Tunai dan ...

Child Hawking in Kano, Nigeria, diakses dari https://ssrn.com/abstract=3279772 , tanggal 5 Maret 2019.

Mustofa, Moh. Deni; Vina Septiana Permatasari. Waqf Management and Zakat Education as A Solution for Economy Improvement through LINKAGE PROGRAMME on UMKM Facing in ASEAN Economics Comunity (AEC) 2015, diakses dari https://www.academia.edu/11777646/Waqf Management and Zakat Education as aSolution for Economy Improvement through LINKAGE PROGRAMME on U MKM Facing in ASEAN Economics Comunity AEC 2015

Nadwi, Mohammad Abdullah, and Mohammed Kroessin. 2013. Cash Waqf: Exploring Concepts, Jurisprudential Boundaries and Applicability to Contemporary Islamic Microfinance Working Paper Series No. 2013 (Microfinance), Islamic Relief Worldwide 2013. http://ssrn.com/abstract $=2384266$, tanggal 5 Maret 2019.

Nafis, M. Cholil. 2015. Aplikasi Wakaf Uang di Indonesia, diakses dari https://bwi.or.id/index.php/publikasi/artikel/974-aplikasi-wakaf-uang-diindonesia.html , tanggal 5 Maret 2019.

Novitasari, Dias. 2018. Pengaruh Wakaf Uang Tunai Produktif terhadap Kesejahteraan Mauqufalaih BWUT MUI DIY dengan Menggunakan Pendekatan Model CIBEST, Skripsi, Fakultas Ekonomi, Universitas Negeri Yogyakarta

Paksi, Girindra Mega., Asfi Manzilati, Marlina Ekawaty. 2018. Kajian Hukum dan Implementasi Wakaf Harta Bergerak di Indonesia: Wakaf Uang dan Saham, ISLAMICONOMIC: Jurnal Ekonomi Islam, Volume 9 No. 2 Juli - Desember.

Peraturan Pemerintah Republik Indonesia Nomor 42 Tahun 2006 tentang Pelaksanaan Undang-Undang Nomor 41 Tahun 2004 tentang Wakaf.

Pitchay, Anwar Allah; Ahamed Kameel Mydin Meera, and Muhammad Yusuf Saleem. 2015. Factors Influencing the Behavioral Intentions of Muslim Employees to Contribute to Cash-Waqf'Through Salary Deductions, JKAU: Islamic Econ., Vol. 28 No. 1, pp: 57-90 (January 2015), DOI: 10.4197 / Islec. 28-1.3

Qudamah, Ibnu. 1997. Al-Mughni wa Syarbul Kabir. Beirut: Darul Alamul Kutub.

Rozalinda. 2011. Efek Ganda Pengelolaan Wakaf Uang. MIQOT: Jurnal Ilmu-ilmu Keislaman Vol. XXXV No. 2 Juli-Desember.

Saadati, Nila. 2016. Efisiensi Produktifitas Wakaf Tunai (Wakaf Uang) dalam Pemberdayaan Ekonomi di Indonesia, Jurnal Muqtasid, Vol. 7 No. 1, Juni.

Sadeq, AbulHasan M. 2002. "Waqf, perpetual charity and poverty alleviation", diakses dari International Journal of Social Economics, Vol. 29 Issue: 1/2, pp.135-151, https://doi.org/10.1108/03068290210413038, tanggal 5 Maret 2019.

Said, Salmah. 2012. Sharia-Based Microfinance Institutions and the Empowerment of Society Economy in Makassar, artikel dipresentasikan pada the $12^{\text {nd }}$ Annual International Conference on Islamic Studies (AICIS), 5 - 8 November 212, di Surabaya.

Ash-Shiddieqy, M. Hasbi. 1998. Falsafah Hukum Islam, Cet ke-3 Bulan Bintang, Jakarta. 
AL-MASHRAFIYAH: Jurnal Ekonomi, Keuangan, dan Perbankan Syariah Volume 3, Nomor 1, April 2019

Subhan, Ahmad. Peran Wakaf sebagai Solusi Awal Kesejahteraan Masyarakat, diakses dari https://www.academia.edu/33006929/Peran wakaf sebagai solusi awal kesejahteraa n masyarakat tanggal 5 Maret 2019.

Suganda, Asep Dadan. 2014. Konsep Wakaf Tunai, ISLAMICONOMIC: Jurnal Ekonomi Islam, Vol. 5, No. 2

Sulistiani, Siska Lis. 2017. Pembaruan Hukum Wakaf di Indonesia. Bandung: Refika Aditama.

Tho'in, Muhammad, dan Iin Emy Prastiwi. 2015. Wakaf Tunai Perspektif Syariah, https://jurnal.stie-aas.ac.id/index.php/jei/article/download/29/28, Jurnal Ilmiah Ekonomi Islam - Vol. 01, No. 01, Maret.

Tuasikal, Muhammad Abduh. 2016. Aturan Penting Wakaf, diakses dari https://seputarwakaf.wordpress.com/tentang-wakaf/dalil-tentang-wakaf/, tanggal 20 Januari 2019.

Tumirin, Iwan Triyuwono, Aji Dedi Mulawarman, and Yeney Widya Prihatiningtias. 2017. Transcendental and Social Accountability in Productive Waqf Assets, Accounting and Finance Review, 2 (1), pp. 9- 16 www.gatrenterprise.com/GATRJournals/index.html

Undang-Undang Nomor 41 Tahun 2004 tentang Wakaf.

Usman, Nurodin. 2015. Studi Hadis-Hadis Wakaf Dalam Kitab Sahih Al-Bukhari dan Fath AlBari, Jurnal Cakrawala, Vol. X, No. 2, Desember.

Wadjdy, Farid dan Mursyid. 2007. Wakaf dan Kesejahteraan Umat "Filantropi Islam yang Hampir Terlupakan. Yogyakarta: Pustaka Pelajar.

ZA, Moh. Ah. Subhan. 2017. Pemberdayaan Wakaf Uang Sebagai Upaya Peningkatan Kesejahteraan Masyarakat, J E S: Jurnal Ekonomi Islam, Volume 2, Nomor 1, September.

Zuhaili, Wahbah. 1985. Al-Fiqh al-Islami wa 'Adillatubu. Damaskus: Darul Fikri al-Mu'ashir.

Subhan, Ahmad. Peran wakaf sebagai solusi awal kesejabteraan masyarakat https://www.academia.edu/33006929/Peran wakaf sebagai solusi awal kesejahteraa n masyarakat 